\title{
LATIN AMERICA AT THE HAGUE CONFERENCE.
}

Perhaps the most salient feature of the Second Peace Conference as compared with its predecessor was the presence of the States of South and Central America, not represented at the First Conference. Brazil was not then sufficiently interested to respond to her invitation and Mexico was the sole representative of Latin America. It seems hard to explain this absence of Latin America from a Conference which reached out beyond Europe to include China, Persia and Siam. Russia may have wished to limit the invitations to the nations represented at the Court of St. Petersburg, fearing the difficulties and obstacles to reaching any agreement which would result from the presence of a too great number of states. Although excluded from the Protocol of the Hague, the nations of Central and South America took its words more to heart than the signatory powers themselves. The desire, expressed by the Conference, for the limitation of armaments had roused no echo were it not that Argentine and Chile in the treaty of May 27th, Ig02, swore friendship based upon obligatory arbitration and the limitation of their armaments. Latin America, too, was quicker than Europe to give heed to the invitation to draw up general and permament treaties of obligatory arbitration-in I902, at the PanAmerican Conference held in the city of Mexico, nine states which had not been represented at The Hague bound themselves by a treaty of that nature. Even those of the South American nations who did not accept the principle of obligatory arbitration joined in praising the work of The Hague Conference. But when they wished to adhere, one and all, to the Convention of July 29th, I899, they found their way barred by the stipulation which closed the treaty to all but signatory powers. The Court was open to all, but not the Convention. This experience convinced them of the necessity of taking part in the next Conference. Certainly their conduct had marked them out among the most worthy to sit in its conclave. They were further encouraged in this course by the United States. In the Pan-American Conferences of Mexico (Ig02) and Rio (1906) the American Government openly advocated their adhesion to the text of the Convention of 1899 and their participation in the 
coming Peace Conference. And so the family of nations in all its branches met together.

No official speech, neither that of the Dutch Minister of Foreign Affairs, nor yet that of Mr. De Nélidow touched upon this circumstance-and only incidentally, on July I6th, Count Prozor, with that fine courtesy which is native to him, thanked the new comers, in a few happy remarks, for the intellectual and moral support they brought the Conference to help it to accomplish its task. It is, however, none the less true that the presence of South and Central America constituted one of the most original characteristics of the Second Peace Conference.

For the first time Europe found herself face to face with Latin America, whose activities were to be no longer confined to the American questions treated in her Pan-American Conferences. Great was the curiosity as to what would be the attitude of this score of new comers towards Europe; the United States and one another.

The enhanced interest their presence gave the proceedings escaped no delegate and was understood throughout the world. The Conference afforded an ideal opportunity for Europe and the United States to observe the political ties and antagonisms of South and Central America. But Latin America was not content to remain an object of political curiosity alone; she made herself felt juridically as well.

At the Hague Conference, South America revealed herself in a twofold aspect-political and juridical. For the better understanding of these two phases it will be well to consider successively the relations of South and Central America: (I) Towards Europe; (2) Towards the United States; (3) Towards one another; (4) As regards their influence upon the formation and development of law.

\section{I.-Attitude towards Europe.}

The countries of Latin America, wonderfully favored by Nature, are too young and too poor to take advantage of their resources without the help of Europe. Immigration furnishes them men and the emission of government bonds their capital. But the instability of some of their governments, which are frequently in the throes of revolution, has often stemmed the influx of both men and money. Bankruptcies following upon political upheavals and pretended bankruptcies manipulated by adventures in control of the machinery of government have been the causes of repeated pecuniary demands on the part of the cabinets of Europe. At times these demands purporting to support the just claims of their subjects have con- 
cealed designs of territorial aggrandizement. They would have used the existence of debt as an excuse to pass by easy stages from the use of force to occupation, and from occupation to annexation. The Monroe Doctrine, which forbids annexation, does not-as Prof. J. B. Moore, in rectification of an error in Wharton's Digest, points out-stand in the way of the use of force. Many a time has Europe had recourse to force to collect her debts without ever going as far as annexation, but the growth of immigration and the expanding greed of Europe have increased the solicitude of South America. When, in I902, England, Germany and Italy, at the end of their patience, girdled a Venezuelan port with their ships of war, Latin America was deeply moved. The Republic of Argentine gave expression to this emotion-Dr. Louis Drago, her Minister of Foreign Affairs, in his memorable note of December 29th, Igo2, said: "In a word, the principle which the Republic of Argentine would like to see recognized is: that public debts cannot occasion armed intervention, much less the actual occupation of the territory of an American nation by a European power."

The United States was ready to respond to an appeal to the Monroe Doctrine, but felt no enthusiasm for the setting up of a new doctrine. At the State Deparment the suggestion of the Argentine statesman was received cordially, but non-committally. The question was brought up again at the Congress of Rio and unanimously referred for discussion to the Second Hague Conference. As the United States were expected to formulate some measure embodying the views of Latin America, they took care to reserve the right to introduce such a proposition. Dr. Drago's presence on the Argentine delegation assured the effective setting forth of his doctrine, ne varietur, especially as Dr. Drago had recently developed his argumentation in published articles in the Revue generale du droit publique and The American Journal of International Law. From the commencement of the Conference his strong and genial personality impressed the delegates and the presentation of his doctrine was impatiently awaited.

It occurred the I8th of July-not in the form of a proposition, but as a declaration. The First Commission was occupied in discussing the extent to which it was possible to enlarge the field of application of arbitration, when Dr. Drago seized upon the occasion to declare that public debts in the form of government bonds should not, under any circumstances, even after arbitration, be collected by force. To quote Dr. Drago's words: "Upon a memorable occasion, the Republic of Argentine proclaimed the doctrine which excludes from the American continent all military operations and 
territorial occupation having their origin in loans contracted by the state. . . It is with this reservation which will be duly submitted, . . . that the Argentine delegation accepts arbitration." As in the case of the note of December 29th, I902, the exclusion of force in the collection of debts only applied in the case of loans contracted by the State, but the Declaration, more far-reaching than the note, not only excluded forcible collection, but even arbitration. Like the power to coin money, Dr. Drago considers the issuing of government bonds to be a sovereign act, and the State which accomplishes an act of sovereignty may not be held for any indebtedness arising from such act, for the act would then cease to be sovereign. None shall question the exercise of the State's sovereign power. The individual towards whom the state, with his acquiescence, had conducted itself as a sovereign, has no right which he can invoke against it, either directly or through the intermediary of the State of which he is a subject. Where the right is non-existent, it is impossible to speak of a remedy or of a judgment. For the claim to the possession of a right necessarily precedes any judgment. Consequently arbitration, as well as the use of force, becomes impossible. Admitting, as we must, the logical deduction of Dr. Drago's argument, it was somewhat shocking in a peace conference to have his conclusion restrict the resort to arbitration, and the United States realized this. While Dr. Drago opposed all use of force, whatever the circumstances, in the case of government bonds, they considered government bonds to be like any other contract, passed by the State, binding upon it and susceptible of being submitted to arbitration. They submitted a proposition in which the illegality of employing force was recognized, at the same time that arbitration in such cases was made obligatory. A nation so minded would still be at liberty to resort to force in the event of a refusal to arbitrate, or failure to execute a sentence so obtained. In other words, the ultimate use of force was left as before to be resorted to by a nation upon its international responsibility, but before proceeding to such extreme measures a state must have submitted its claim to arbitration, or at least, made an offer so to do which the debtor state had left unanswered. A guarantee was obtained against the abuse of force. The motive for the use of force in such cases in the future may remain the same; that is to secure payment. The immediate cause, however, will be the refusal of the debtor state to arbitrate or its failure to conform with the sentence rendered. The great principle of obligatory arbitration has at last gained a foothold within the laws of nations. 
Dr. Drago made a mistake in presenting before a commission of arbitration a theory restricting instead of extending arbitration. Further, he should not have brought forward reasons-for they must always be juridical and hence, open to discussion-to support a doctrine claiming to be political in its nature, and therefore not open to discussion. He thought to strengthen his contention by relying on the juridical distinction between the ordinary contract performed jure gestions (Act of Administration) and the contract of a government loan performed jure imperii (Act of Authority), but he only weakened it. For, though differing in form, both are in reality Acts of Administration,- - not in the least Acts of Sovereignty. An Act of Sovereignty is a command, but an offer to deliver government bonds to foreign capitalists, is not. The state does not impose bonds on the capitalists of the foreign money market, as it does its currency within its territory. The fallacy of Dr. Drago's basing his doctrine on juridical sovereignty did not escape the learned jurist, who represented Brazil. Sr. Ruy Barbosa, in a masterly speech, outlined the history of the question, praising the initiative of Dr. Drago which gave rise to his doctrine and remarking upon the sound financial condition of Argentine and her consequent disinterestedness in the question. But Brazil could only subscribe to the pacific tendencies contained in Dr. Drago's doctrine concerning the collection of state debts. She could not admit an irresponsibility based upon sovereignty. A state which contracts a loan does not accomplish a political act, but an ordinary legal operation, and although the loan contracted is not due to a specified person, the same is true of other debts, yet no one thinks of excluding them from the domain of the law. Not content with assailing the juridical nature of the Drago Doctrine, the Brazilian Ambassador attacked its political side. It appealed to the support of the Monroe Doctrine. "What the Monroe Doctrine prohibits is only territorial occupation and annexation, not the use of force; blockades or bombardments, provided they be not followed by annexation. To make the Monroe Doctrine a shield to delinquent debtors would be to compromise it. Finally, considered from an economic point of view, the only result of the Drago Doctrine would be to close to new countries the money markets where the capital necessary to their development is to be found, and so to paralyze the very independence which the doctrine seeks to protect."

This beautiful speech made a profound impression upon the Conference. Sr. Barbosa had brought forward against the juridical side of the Drago Doctrine all the arguments which Europe could have advanced, and as for the political aspect, he had said emphatically what the United States thought, but could hardly 
express,-that the Drago Doctrine was not a simple application of the Monroe Doctrine, but an extension, and of such a nature as to cast discredit upon the original doctrine. Speaking with the authority which in such a matter could only belong to a son of South America, he demonstrated that the Drago Doctrine might be dangerous to the vital interests of Latin America.

Almost all the states of South and Central America, called upon to express their opinion, made the preliminary declaration that when the courts of the debtor state were competent to take cognizance of these claims, the resort to arbitration could only be exacted in the case of a denial of justice. Cuba, Haiti and Mexico, convinced by the arguments of the first delegate of Brazil, accepted the American proposition,* while Argentine, Guatemala, Nicaragua and Salvador accepted with the proviso that they intended to maintain the Drago Doctrine. Chile, admitting the faculty to have recourse to the forcible collection of debt, accepted the American proposition, but wished to extend its scope to embrace all disputes of a pecuniary origin. It must, however, be remembered that Dr. Drago used his powerful influence to secure the adoption of the "Porter Proposition," and although he differed as to the extent to which the American project was applicable, his reservation secured to his country the right to exclude from its operation debts arising from government bonds.

II.--Attitude towards the United States.

What, apart from this question, which, although of vital interest to South America, was only an incident in the great work of the Conference, was going to be the attitude of the nations of Latin America regarding the important questions of war and peace contained in the program of the Conference? Would they entertain their own views independently of North America? Europe, coming to the Hague, confidently expected to find the states of America grouped about the United States and following their lead in almost every question. This illusion was soon dispelled. For no sooner had the Fourth Commission, which treated of maritime warfare, begun its difficult task, when it became evident that the states of South and Central America were acting upon their own initiative and that their attitude in each case was determined by their own

* The contending powers agree not to have recourse to force of arms for the collection of debts which have their origin in contracts and which the government of one country exacts in behalf of its citizens from the government of another.

Nevertheless this agreement shall not apply in case the debtor state refuses or leaves unanswered the offer to arbitrate, or when, having accepted, it renders the drawing up of a compromise impossible, or when, after arbitration, it fails to comply with the decision. 
understanding of how their interests lay. When Mr. Choate, carrying out the initiative of $\mathrm{Mr}$. White at the First Conference, brought forward the proposition for the immunity of private property at sea even when under the enemy's flag, Brazil voted in favor of the proposal, but Sr. Barbosa hastened to explain that she did so, not out of any complacency to the United States, but in conformity with her traditional policy dating back more than half a century. Moreover, that Brazil had signed the Declaration of Paris which the United States had counseled her to reject. (Speech of Ruy Barbosa, July I5, I907.) Colombia did not hesitate to oppose the proposition of Mr. Choate. In words of veiled irony, Sr. Triana recognized the disinterestedness of the United States; but Colombia could not afford to pursue an ideal for the sole good of humanity. The eyes of greed were upon her. In closing he said: "A country like ours without a merchant marine and almost without a navy, but which in time of war might increase it, has all to lose and nothing to gain by the suppression of the right of capture." Similar reasons led Argentine to make a like declaration, though milder in form. On the side of the United States, besides Brazil, were Cuba, Ecuador and Haiti, while Argentine, Mexico, Panama and Salvador joined in the opposition with Colombia. Chile abstained and the other countries of South America did not participate in this historic vote.

The United States had a divided following for their own proposition, but when it came to the British proposal to abolish contraband of war the opposition of the United States, which went even to the extent of a reversal of her former policy, was not sustained by a single nation of America. Cuba voted for the abolition and Panama abstained. Some of the states, like Chile, wished to assure their commerce in nitrate of soda; others, like Brazil, intended to live up to the spirit of progress which had made them vote for the immunity of private property; still others, like Argentine, though favorable to the capture of private property, thought to assure themselves in the event of war a greater commerce at the price of their neutrality.

Generally speaking, the lack of railroads makes the countries of South and Central America, as is the case with England, dependent upon the sea for their supplies. Hence, their hostility to the seizure of contraband of war. This last reason also explains Brazil's demand for a strict interpretation of the effectiveness of blockades. This is contrary to the views of the United States. To illustrate, it will suffice to examine a provision of the Brazilian proposition concerning blockades, which makes a ship headed for a blockaded 
port liable to capture in the neighborhood only of the blockading force, while the United States, in their proposition, would permit the seizure the moment the voyage to the blockaded port had commenced. A country like Brazil, depending upon its seaboard for its existence, cannot be too careful in guarding against any extension of the right of blockade.

Because the population of the states of South and Central America is less in density and in numbers than that of the United States; because their communication by railroads are less developed, and because they are poorer and weaker, it follows naturally that their views as to what should constitute the rules of war are at variance with those of North America. The same is true of their views for the establishment of peace.

When Mr. Choate, followed by Dr. Scott, unfolded the plan, so rich in possibilities, for a court really permanent, composed of a small number of judges in constant readiness to examine the affairs brought before them, the states of South America were favorably disposed. They felt that such a court would develop arbitration. The United States flattered their national pride by proposing to apportion the judges among the forty-five countries represented at the Conference, so as to take into account not only the number of inhabitants of each, but the different systems of law and principal languages. Among the latter, Spanish would, of course, figure. They were happy to find in the project, as outlined by Dr. Scott, solicitude for their language as well as security for the maintenance of their law; consequently, the vote of the Americans to take up the discussion of the project was cast (August $3 \mathrm{rd}$ ) as a unit. But harmony was at an end when the Special Committee reached the discussion of the basis for the distribution of the judges. When it was proposed to place the greatest of the South American states in a class below some of the second rate powers of Europe they were loud in their indignation. The authors of the project-it must be said to do them justice-felt that the total representation of South America would be great in any event; that entering for the first time into the European concert Latin America might be expected to take a modest attitude and allow to some of the rather insignificant European states with glorious pasts but little in the present, a place which they might hold in the limited horizon of Europe, but to which they were by no means entitled when their influence, actual and potential, was compared with the foremost states of Latin America. It seemed hopeless otherwise, in the tangle of European alliances and royal marriages to find any workable plan. The main difficulty in finding a solution was due to Brazil. 
The jealousy of certain South American states would have made them vote against any proposal which ranked Brazil above them on the score of her superior population. Argentine maintained that the development of their country made its half dozen millions weigh in the balance with Brazil's score. August I7th Dr. Scott submitted a preliminary plan of distribution in which Brazil found herself in the third class with Argentine and Chile, and among European countries placed in this class were to be found Denmark and Roumania.

At the next meeting, Sr. Ruy Barbosa, in a remarkable speech attacked the American plan, and all the countries who felt aggrieved by the proposed apportionment of the judges rallied to his support. The Brazilian ambassador dissected the American proposition and showed up its glaring inconsistency with the principal of the equality of states. He had the whip handle and he used it. Perhaps few of the delegates believed in the time-honored theory of the equality of states, but it would hardly have done to say so. The Brazilian delegate employed his great oratorical talent to prevent the success of the American project. Many times the original proposition was modified to try to give satisfaction to the legitimate demands of all states, but Sr. Barbosa, with the greater part of South America at his back, prolonged his opposition. At bottom the states of South America felt that every day brings an advance in the economic and political development of South America and adds to their power and influence throughout the world. They did not desire to see a court established on the basis of their present status in the family of nations-just as Germany, feeling she has no room to grow, opposed obligatory arbitration which would have a tendency to maintain indefinitely the actual territorial distribution of the world.

While it is true that Sr. Barbosa's opposition prevented the arrival at any agreement as to the system for the selection of judges, he seems at the very end of the Conference to have helped to secure the unanimous approval of the remaining articles of the court project by the Conference with the expression of its desire for the actual establishment of the court as soon as the signatory powers might agree upon the method of choosing the judges.

III.-South and Central America in timeir Relations with One Another.

The relations of the states of South and Central America amongst themselves were most interesting from a political point of view. It sometimes happened that their interests lay together in some one question, as in the case of the abolition of contraband, or the deter- 
mination of the principle to serve as a basis for the apportioning of the judges of the Permanent Court. In general, however, their interests were opposed, as in the instances of the immunity of private property and the forcible collection of debt, and these differences between the states were, if anything, accentuated by the rivalry between their delegates. Brazil, championed by her learned orator, and Argentine, supported by the eloquence and juridical attainments of Dr. Drago, contested the leadership of South America-an honor which not a few countries of Europe might envy. But from under this praiseworthy rivalry peeped out political antagonisms; words were spoken which smelt the powder and theories which seemed to contemplate war propounded. In the Third Commission (rights and duties of neutrals) Sr. Barbosa brought forward an amendment to authorize the delivery to a belligerent of vessels of war under construction in a neutral state, provided they should have been ordered six months before the outbreak of the war. A state might, in this manner, by renewing her orders every six months, be sure of securing delivery of all the ships she might need. It is significant that in a subsequent session, Dr. Drago attacked this proposal with great vigor-so forcible was he that it seemed as though Argentine felt herself menaced.

During the first few weeks of the Conference it was bruited about among the Latin Americans that Brazil, unmindful of her duties as a State of South America, followed in the wake of North America. This idle rumor, perhaps put in circulation by the enemies of Brazil, may have wounded the sensitive temperament of the first Brazilian delegate and have inclined him more strongly to that opposition to the American proposals which has had such lamentable consequences. Difficult as it is to explain the hostility of the other South and Central states towards Brazil, it is useless to deny the fact, but Sr. Barbosa, by marshalling the discontent of South America against the Permanent Court project did much to mollify this feeling, at least as far as the Conference went. It may be hoped that the precedent set by Argentine and Chile in peaceably settling their rivalry when at the very verge of war may not be departed from in South America nor elsewhere.

IV.-General Influence upon the Development of Law.

What part has Latin America played in the progress and success of the Second Peace Conference? She has shown, in a most emphatic manner, that she must be heard upon all questions, and that when united, her veto to any proposition is decisive. But further, she has shown capacity to construct. 
The old Article 27 of the Convention for the Peaceful Adjustment of International Differences which read as follows:

"The Signatory Powers consider it their duty, if a serious disputc threatens to break out between two or more of them, to remind these latter that the Permanent Court is open to them.

"Consequently, they declare that the fact of reminding the conficting parties of the provisions of the present Convention, and the advice given to them, in the highest interests of peace, to have recourse to the Permanent Court, can only be regarded as friendly actions."

was modified in accordance with the Peruvian and Chilean Amendments by the addition of:

"In case of a dispute between two powers, either may always address a note to the International Bureau at the Hague, containing its declaration that it is disposed to submit the dispute to arbitration.

"The Bureau shall immediately bring this declaration to knozeledge of the other power."

As thus completed, Article 27 has become Article 48 of the Modified Convention, which still bears the date of the old Convention,

Any state may now send a note to the International Bureau at the Hague that it is willing to arbitrate the dispute, and this offer will be transmitted to the other state. Any country which declares war without responding to such an offer will have the force of the public opinion of the civilized world against it. It will hesitate before taking such a course, and if, as a result of this respite, better councils prevail and a conflict is avoided, the world will owe its peace to this Latin American Amendment. The few words added to the old article are likely to be of far-reaching and everlasting importance.

Of an entirely different nature was the Brazilian proposition to make it impossible to arbitrate questions relating to inhabited territory without the previous consent of its inhabitants. Here the present practical value is small, but this doctrine may perhaps be of great interest for the future.

The study of the discussions reveals how powerfully Sr. Barhosa's masterful defense of the principles of the equality of states and the independence of national institutions influenced the deliberations of the delegates. And Dr. Drago's illuminating remarks upon the treaty-making power dispelled many illusions.

Both men have done much to advance science and have increased the respect which is entertained for the countries they represented.

The nations have come together from the four corners of the earth. A new era has opened for Latin America.

A. G. de Lapradelle, Ellery C. Stowell. 